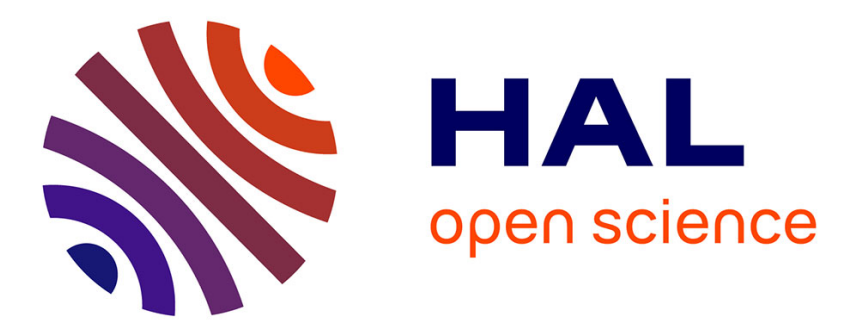

\title{
( $\mathrm{n}-\mathrm{Bu} 2 \mathrm{Sn}) 2 \mathrm{O}(\mathrm{CO} 3)$ : An active, robust and recyclable organotin(IV) for the direct synthesis of linear organic carbonates from carbon dioxide and alcohols
}

Sreevardhan Reddy Sanapureddy, Laurent Plasseraud

\section{- To cite this version:}

Sreevardhan Reddy Sanapureddy, Laurent Plasseraud. ( n -Bu 2 Sn) 2 O(CO 3 ): An active, robust and recyclable organotin(IV) for the direct synthesis of linear organic carbonates from carbon dioxide and alcohols. Applied Organometallic Chemistry, 2017, 31 (11), 10.1002/aoc.3807 . hal-03547388

\author{
HAL Id: hal-03547388 \\ https://hal.science/hal-03547388
}

Submitted on 28 Jan 2022

HAL is a multi-disciplinary open access archive for the deposit and dissemination of scientific research documents, whether they are published or not. The documents may come from teaching and research institutions in France or abroad, or from public or private research centers.
L'archive ouverte pluridisciplinaire HAL, est destinée au dépôt et à la diffusion de documents scientifiques de niveau recherche, publiés ou non, émanant des établissements d'enseignement et de recherche français ou étrangers, des laboratoires publics ou privés. 


\title{
$\left(n-\mathrm{Bu}_{2} \mathrm{Sn}\right)_{2} \mathrm{O}\left(\mathrm{CO}_{3}\right):$ An active, robust and recyclable organotin(IV)
}

\section{for the direct synthesis of linear organic carbonates from carbon}

\section{dioxide and alcohols}

\author{
Sreevardhan Reddy Sanapureddy and Laurent Plasseraud* \\ Institut de Chimie Moléculaire de l'Université de Bourgogne (ICMUB), UMR-CNRS 6302, \\ Université de Bourgogne Franche-Comté, 9 avenue A. Savary, F-21078 Dijon, France \\ Received; accepted \\ * Correspondence to: Laurent Plasseraud, Tel.: +33 380399160; fax: + 33380396117 \\ E-mail: laurent.plasseraud@u-bourgogne.fr
}

\begin{abstract}
Organotin(IV) compounds are known to promote the direct synthesis of organic carbonates from carbon dioxide and alcohols. In the past, structural studies have highlighted that the carbonato moiety is a recurring ligand of tin species collected during the $\mathrm{CO}_{2}$ pressurized reactions. In a mimetic approach and in order to achieve an available and recyclable precursor, the title compound, $\left(n-\mathrm{Bu}_{2} \mathrm{Sn}\right)_{2} \mathrm{O}\left(\mathrm{CO}_{3}\right)(\mathbf{1})$ was prepared in a single step by reacting commercial di- $n$-butyltin dichloride with an aqueous solution of sodium carbonate. $\mathbf{1}$ was characterized by infrared spectroscopy, thermogravimetric and elemental analysis. Multinuclear NMR investigations in solution were also conducted. 1 was then evaluated for the direct carbonation of alcohols (methanol, ethanol, $n$-butanol and isopropanol) under $\mathrm{CO}_{2}$ pressure. Recycling experiments were performed showing the efficient reuse of $\mathbf{1}$ without loss of activity. Furthermore the infrared fingerprint of $\mathbf{1}$ was preserved even after several runs demonstrating a good stability. The effects of pressure and of reaction time on the DMC formation were also studied.
\end{abstract}


Keywords: Carbon dioxide utilization; Alcohols conversion; Linear organic carbonates; Diorganotin(IV); Carbonato complex.

\section{Introduction}

The past two decades have witnessed a steadily growing interest in the chemical transformation of carbon dioxide into chemicals with higher value-added. The large number of review articles published on this field in recent years [1], as well as the periodically organization of several international events [2] reflect the strong attention and involvement of the scientific community worldwide. Considered initially as a waste, in particular partially responsible for the greenhouse effect, carbon dioxide is increasingly seen as a potential valuable raw-material. Thus, with the depletion of fossil fuels, $\mathrm{CO}_{2}$ can be considered as an alternative and abundant source of carbon, acting as $\mathrm{C} 1$-building blocks. To date a wide range of $\mathrm{CO}_{2}$-based syntheses have been identified leading to several class of commodity chemicals, some of them have been produced at an industrial scale for a long time.

Organic carbonates, $(\mathrm{RO})_{2} \mathrm{CO}$, also called carbonic esters represent historical target molecules of the concept of $\mathrm{CO}_{2}$ utilization, often considered as a case study. They are classified in three groups. Depending on the nature of R, they can be linear, cyclic or polymeric. Highly oxygenated and polar, organic carbonates are considered as environmentally friendly and used for different types of applications. Dialkyl carbonates are increasingly used as solvent in organic synthesis and homogeneous catalysis, taking advantage of their green character [3]. Conventionally organic carbonates are prepared from hazardous reactants such as phosgene and carbon monoxide. The alternative routes involving $\mathrm{CO}_{2}$ are particularly attractive in terms of green chemistry and atom economy. While the synthesis of cyclic carbonates by reacting oxiranes with $\mathrm{CO}_{2}$ has been widely studied and is now well documented [4], the direct synthesis 
of linear organic carbonates from alcohols and $\mathrm{CO}_{2}$ still arouses a strong interest from academic groups and continues to be a real challenge. In this context and from an organometallic chemistry point of view, organotin(IV) compounds are recognized from a long time as efficient precursors for the transformation of carbon dioxide into linear alkyl carbonates (Eq. 1).

$$
\mathrm{CO}_{2}+2 \mathrm{ROH} \longrightarrow(\mathrm{RO})_{2} \mathrm{CO}+\mathrm{H}_{2} \mathrm{O}
$$

Since the preliminary work of Kizlink during the 90s [5], several groups have reported the beneficial use of tin complexes for the carbonate synthesis, directly in solution [6] or grafted on various supports [7]. Furthermore, organotin(IV) compounds are also known to be effective for the $\mathrm{CO}_{2}$-based synthesis of 2-oxazolidones [8] and carbamates [9]. In our group, we especially focused on diorganotin(IV) alkoxides $\mathrm{R}_{2} \mathrm{Sn}(\mathrm{OR})_{2}\left(\mathrm{R}=n\right.$-Bu, tert-Bu, $\mathrm{Bz} ; \mathrm{R}^{\prime}=\mathrm{Me}$, Et, $\left.{ }^{i} \mathrm{Pr}\right)$. We studied in particular the $\mathrm{CO}_{2}$ insertion into the Sn-OR bond and the assistance role of these complexes for the direct carbonation of alcohols (Eq. 1) [10]. Recently we supported mechanistic insights by high-pressure NMR spectroscopy studies in a sapphire tube [11].

Interestingly, when dialkoxide diorganotin(IV) compounds are used as precursors, we characterized by X-ray diffraction analysis and during recycling experiments, unexpected structures of polynuclear oxodiorganotin(IV) complexes bearing carbonato ligands [12]. Two of them obtained for the di-tert-butyl and di-n-butyl derivatives, respectively, are depicted in scheme 1. Moreover, solid state ${ }^{119}$ Sn NMR investigations conducted on insoluble organotin residues collected from high pressure reactions have led to suggest the formation of cross-linked networks based on a central contribution of the carbonato ligands (Scheme 2) [13]. Thus, organotin carbonates occupy a preponderant role in tin-catalyzed organic carbonate synthesis. 
(a)

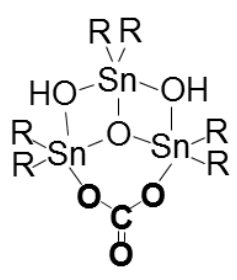

$\mathrm{R}=$ tert $-\mathrm{Bu}$ (b)

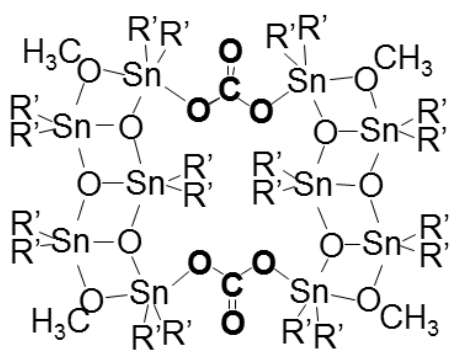

$\mathrm{R}^{\prime}=n-\mathrm{Bu}$

Scheme 1. Molecular representations of (a) $\left[\mathrm{OC}\left(\mathrm{OSn} \text {-tert- } \mathrm{Bu}_{2}\right)_{2} \mathrm{O} \cdot\right.$ tert $\left.-\mathrm{Bu}{ }_{2} \mathrm{Sn}(\mathrm{OH})_{2}\right][12 \mathrm{a}]$, and (b) $\left(n-\mathrm{Bu}_{2} \mathrm{SnO}\right)_{6}\left[\left(n-\mathrm{Bu}_{2} \mathrm{SnOCH}_{3}\right)_{2}\left(\mathrm{CO}_{3}\right)\right]_{2} \quad[12 \mathrm{~b}]$ which were obtained during recycling experiments and isolated at room temperature as single crystals from methanolic solutions.

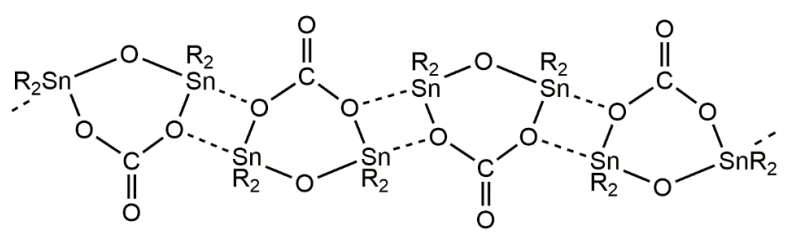

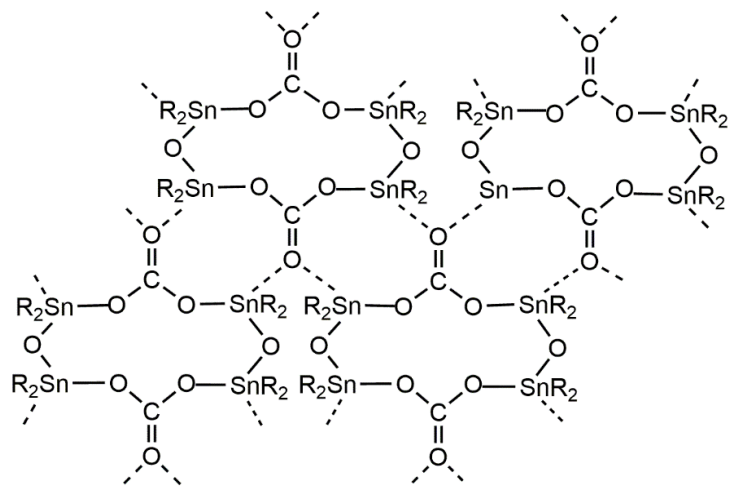

Scheme 2. Possible arrangements of oxycarbonate-based networks $(\mathrm{R}=n$ - $\mathrm{Bu})$ [13].

Based on these previous experimental results and with the aim of a mimetic approach, we seek to develop a simple, robust, and recyclable precursor for the direct synthesis of linear dialkyl carbonates from alcohols and carbon dioxide. We report in this paper the preparation, the characterization and the activity evaluation of $\left(n-\mathrm{Bu}_{2} \mathrm{Sn}\right)_{2} \mathrm{O}\left(\mathrm{CO}_{3}\right)$ for the direct carbonation of various primary alcohols.

\section{Results and discussion}




\section{Synthesis and characterization of $\left(n-\mathrm{Bu}_{2} \mathrm{Sn}\right)_{2} \mathrm{O}\left(\mathrm{CO}_{3}\right)(1)$}

The preparation and characterization of carbonates derivatives of organotin complexes were initially studied from the 60 s to 80 s [14]. Since then, and due to the growing interest for the $\mathrm{CO}_{2}$ activation, several compounds were isolated as single crystals and their structures have been fully resolved. In general the carbonato ligand exhibits $\mu_{2}-\mathrm{O}, \mathrm{O}^{\prime}$ [15] and $\mu_{3}-\mathrm{O}, \mathrm{O}^{\prime}, \mathrm{O}^{\prime \prime}$ [16] coordination modes, linking distinct tin atoms and leading to the formation of polynuclear and polymeric structures. Rare examples of organotin carbonates with terminally $\mathrm{CO}_{3}$ moiety have been recently reported by Jambor and co-workers for mononuclear tin complexes [17]. In 1976, Goel and co-workers reported the synthesis and the characterization of $\left(\mathrm{Me}_{2} \mathrm{Sn}\right)_{2} \mathrm{O}\left(\mathrm{CO}_{3}\right)$ by reacting an aqueous solution of potassium carbonate with an acetone solution of dimethyltin dichloride [14b]. Interestingly, previously we concluded on the basis of solid-state NMR experiments that the tin-residue collected from the direct carbonation of alcohols was related to the oxycarbonate structure advanced by Goel [13]. Therefore, we decided to prepare the $n$-butyl analogue to $\left(\mathrm{Me}_{2} \mathrm{Sn}\right)_{2} \mathrm{O}\left(\mathrm{CO}_{3}\right)$ by adding an aqueous solution of sodium carbonate to a methanolic solution of di-n-butyltin dichloride (Eq. 2).

$$
2 n-\mathrm{Bu}_{2} \mathrm{SnCl}_{2}+2 \mathrm{Na}_{2} \mathrm{CO}_{3} \stackrel{\text { ii) } P_{\mathrm{CO} 2} 60 \mathrm{bar}, 150^{\circ} \mathrm{C}, 24 \mathrm{~h}}{-4 \mathrm{NaCl}} \quad\left(n-\mathrm{Bu}_{2} \mathrm{Sn}\right)_{2} \mathrm{O}\left(\mathrm{CO}_{3}\right)+\mathrm{CO}_{2}
$$

The initial Goel's procedure was modified by keeping for $24 \mathrm{~h}$ the reaction mixture under $\mathrm{CO}_{2}$ pressure (see experimental part). Indeed, we observed experimentally that the conditions used for the synthesis of $\left(\mathrm{Me}_{2} \mathrm{Sn}\right)_{2} \mathrm{O}\left(\mathrm{CO}_{3}\right)\left(\mathrm{CO}_{2}\right.$-saturated acetone solution) were insufficient for the preparation of $\left(n-\mathrm{Bu}_{2} \mathrm{Sn}\right)_{2} \mathrm{O}\left(\mathrm{CO}_{3}\right)$. Thus, the infrared spectra recorded from the material synthesized according to the Goel's conditions showed that the carbonate bands $\left(v_{\mathrm{as}} \mathrm{CO}_{3}\right.$ and $v_{\mathrm{s}} \mathrm{CO}_{3}$ ) exhibited much lower intensities than expected (Fig. S1a). In addition, the decarbonation occurs rapidly from $100{ }^{\circ} \mathrm{C}$ (Fig. S1b). A $\mathrm{CO}_{2}$ pressure treatment was found to be beneficial leading to IR data consistent with the Goel's description. Finally, ( $n$ - 
$\left.\mathrm{Bu}_{2} \mathrm{Sn}\right)_{2} \mathrm{O}\left(\mathrm{CO}_{3}\right)(\mathbf{1})$ was obtained as a white solid which turns out insoluble in most common organic solvents. Several batches were synthesized with yields in the range of $35-45 \%$. The elemental analyses confirm the reproducibility of $\mathbf{1}$ and are in agreement with the expected theoretical formula (Table 1). The tin content of one of the batches was also determined by ICPAES and matches satisfactorily with $\mathrm{C}_{17} \mathrm{H}_{36} \mathrm{O}_{4} \mathrm{Sn}_{2}$ (found: $\mathrm{Sn}=45.95 \%$; calculated: $\mathrm{Sn}=$ $43.82 \%)$.

Tableau. 1. Elemental analyses of several batches of $\mathbf{1}$.

\begin{tabular}{|c|c|c|c|c|}
\hline$\%$ Batch No. & 1 & 2 & 3 & $\begin{array}{c}\text { Theoretical } \\
\text { values }^{\mathrm{a}}\end{array}$ \\
\hline Carbon & 37.69 & 37.68 & 37.61 & 37.68 \\
\hline Hydrogen & 7.02 & 6.70 & 7.50 & 6.70 \\
\hline
\end{tabular}

${ }^{\mathrm{a} C a l c u l a t e d ~ f o r ~} \mathrm{C}_{17} \mathrm{H}_{36} \mathrm{O}_{4} \mathrm{Sn}_{2}$

The infrared spectrum of a fresh sample of $\mathbf{1}$ (ATR mode), dried under vacuum at room temperature (Figure S2a), also corroborates the organotin oxycarbonate structure. The $n$-butyl chains are distinctly identified by the vibration bands located in the range of $3000-2900 \mathrm{~cm}^{-1}$ $\left(v_{\mathrm{C}-\mathrm{H}}\right)$. The carbonate function is recognizable by the two large bands at 1507 and $1371 \mathrm{~cm}^{-1}$, and corresponding to asymmetric and symmetric $v_{\mathrm{CO} 3}$ stretching elongations, respectively. In the past, comparable values which characterize bridging carbonate groups were reported by Goel for $\left(\mathrm{Me}_{2} \mathrm{Sn}\right)_{2} \mathrm{O}\left(\mathrm{CO}_{3}\right)[14 \mathrm{~b}]$. The bands in the $650-500 \mathrm{~cm}^{-1}$ region reflect $\mathrm{Sn}-\mathrm{O}$ bonds. Increasing the temperature during the drying stage does not induce significant changes on the structure of 1, the infrared fingerprints remain strictly comparable (Figures S2b and S2c). However at $150{ }^{\circ} \mathrm{C}$ the spectrum undergoes substantial transformations. The characteristic absorptions of the carbonate function disappeared leading unambiguously to the formation of di-n-butyltin oxide (Figure S2d). 
The thermogravimetric analysis (TGA) of $\mathbf{1}$ was carried out under nitrogen atmosphere at a heating rate of $5^{\circ} \mathrm{C} \mathrm{min}^{-1}$ (Figure 1). A major weight loss of $8 \%$ is recorded in the range of $149-160^{\circ} \mathrm{C}$, it can be attributed to the release of carbon dioxide. The $\mathrm{CO}_{2} \mathrm{wt} \%$ calculated for $\left(n-\mathrm{Bu}_{2} \mathrm{Sn}\right)_{2} \mathrm{O}\left(\mathrm{CO}_{3}\right)(\mathbf{1})$ is 8.12 which is very close to the loss experimentally observed. This analysis support also the formula of $\mathbf{1}$.

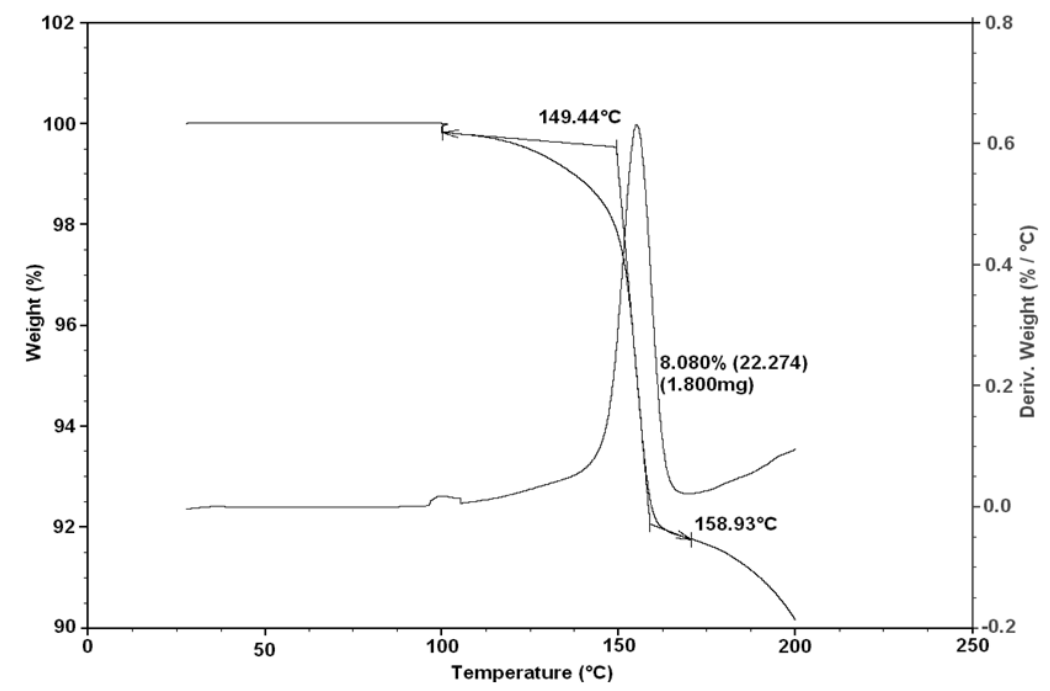

Figure 1. TG-DTG analyses of $\mathbf{1}$ focusing the loss of $\mathrm{CO}_{2}$.

The characterization of $\mathbf{1}$ was also undertaken by multinuclear NMR measurements in solution. Despite a very low solubility, ${ }^{1} \mathrm{H},{ }^{13} \mathrm{C}\left\{{ }^{1} \mathrm{H}\right\}$ and ${ }^{119} \mathrm{Sn}\left\{{ }^{1} \mathrm{H}\right\}$ data could be collected from a solution of 1 in $\mathrm{CD}_{3} \mathrm{OD}$ (in the presence of $\mathrm{CO}_{2}$ ). The ${ }^{1} \mathrm{H}$ and ${ }^{13} \mathrm{C}\left\{{ }^{1} \mathrm{H}\right\}$ spectra depicted in Figures S3 and S4, respectively, show the characteristic signals of the $n$-butyl chains linked to Sn. Two sets of signals are observed on the ${ }^{13} \mathrm{C}\left\{{ }^{1} \mathrm{H}\right\}$ spectrum. A ${ }^{1} J_{\mathrm{CSn}}$ coupling of the order of $600 \mathrm{~Hz}$ could also be measured. In addition, a weak signal visible at $160.1 \mathrm{ppm}$ can be assigned to the carbonyl group of the carbonate moiety. On the ${ }^{119} \mathrm{Sn}\left\{{ }^{1} \mathrm{H}\right\}$ NMR spectrum (Figure S5), two resonances (broad signals) located at -173.5 and $-205.6 \mathrm{ppm}$ are detected, exhibiting a 1:1 relative integration. Such chemical shifts suggest the presence of tin atoms in a pentacoordinate 
environment. The involvement of the carbonato ligands in intermolecular interactions is assumed, which probably leads to the formation of polymeric structures (explicating the difficulties encountered for the solubilisation of $\mathbf{1}$ ).

\section{Synthesis of linear organic carbonates}

Firstly, 1 was employed as precursor for the synthesis of dimethyl carbonate (DMC) from methanol and $\mathrm{CO}_{2}$ (Eq. 1, $\mathrm{R}=\mathrm{Me}$ ). The reaction was carried out at $150{ }^{\circ} \mathrm{C}$, under $200 \mathrm{bar}$ of pressure for $24 \mathrm{~h}$. As expected, $\mathbf{1}$ is active for the DMC synthesis showing an almost complete selectivity (Fig. 2, run 1). After separating the volatiles by a trap-to-trap distillation $(\mathrm{MeOH}$, DMC), the tin-based residue can be reuse efficiently for several runs in the presence of new charges of methanol (20 mL) and $\mathrm{CO}_{2}$ (Fig. 2, run 2-7). The amount of DMC increases even slightly compared to the first run. However no conversion of DMC was noted in the absence of tin residue. The same observation was made using only $\mathrm{Na}_{2} \mathrm{CO}_{3}$ as precursor. The activity of di-n-butyltin carbonate was also tested in the presence of 2,2-dimethoxypropane (DMP), used as a dehydrating agent. DMP which is an acetal, is known to react in situ with the water formed, thus promoting the displacement of the carbonation reaction to the right [18]. Acetone resulting from the hydrolysis of DMP, is proving to be inert to the carbonation reaction. However, a significant effect was observed on the DMC amount (Fig 2, run 5) which is growing even more with a longer reaction time (Fig 2, run 6). 


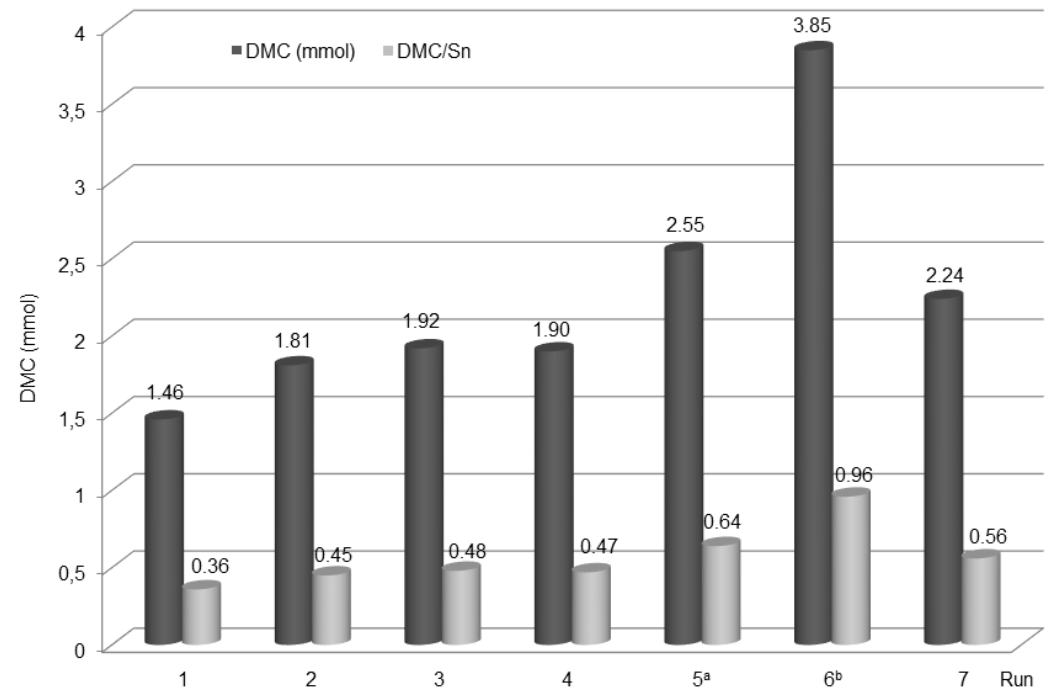

Figure 2. Recycling experiments. Reaction conditions: $20 \mathrm{~mL}$ of $\mathrm{MeOH}, 4 \mathrm{mmol}$ of $\mathbf{1}$ (run 1), reaction temperature $150{ }^{\circ} \mathrm{C}$, pressure 200 bar, reaction time $24 \mathrm{~h} .{ }^{\text {a }}$ addition of $10 \mathrm{mmol}$ of DMP. ${ }^{\mathrm{b}}$ addition of $10 \mathrm{mmol}$ of DMP, reaction time $48 \mathrm{~h}$.

At the end of each run, the infrared fingerprint of the tin-based residues was recorded and compared to 1. Interestingly, as demonstrated on Figure S6, the spectra are almost similar. Thus, $\left(n-\mathrm{Bu}_{2} \mathrm{Sn}\right)_{2} \mathrm{O}\left(\mathrm{CO}_{3}\right)$ does not undergo significant changes during the successive runs and is recovered without alteration. Elemental analyses also support the preservation and the stability of $\mathbf{1 .}$

Tableau. 2. Elemental analyses of tin residues.

\begin{tabular}{|c|c|c|c|}
\hline$\%$ Run No. & 2 & 3 & \begin{tabular}{c} 
Theoretical $_{\text {values }^{\mathrm{a}}}$ \\
\hline Carbon
\end{tabular} \\
\hline Hydrogen & 6.63 & 37.48 & 37.68 \\
\hline
\end{tabular}

${ }^{\mathrm{a} C a l c u l a t e d}$ for $\mathrm{C}_{17} \mathrm{H}_{36} \mathrm{O}_{4} \mathrm{Sn}_{2}$ 
In the presence of DMP, infrared spectra of the residues highlight a noteworthy evolution (Figure S7a and S7b). In addition to the spectrum of 1, three additional bands appear at 2804,1539 and $1062 \mathrm{~cm}^{-1}$ and can be attributed to $v_{\mathrm{OC}-\mathrm{H},} v_{\mathrm{CO} 3}$ and $v_{\mathrm{O}-\mathrm{C}}$ absorptions, respectively. They remarkably match with the signature of the deca-tin compound, $(n-$ $\left.\mathrm{Bu}_{2} \mathrm{SnO}\right)_{6}\left[\left(n-\mathrm{Bu}_{2} \mathrm{SnOCH}_{3}\right)_{2}\left(\mathrm{CO}_{3}\right)\right]_{2}$, depicted in Scheme 1 and fully characterized in the past $[12 \mathrm{~b}, 13] .\left(n-\mathrm{Bu}_{2} \mathrm{SnO}\right)_{6}\left[\left(n-\mathrm{Bu}_{2} \mathrm{SnOCH}_{3}\right)_{2}\left(\mathrm{CO}_{3}\right)\right]_{2}$ consists of two pentameric ladders, $(n-$ $\left.\mathrm{Bu}_{2} \mathrm{Sn}\right)_{5} \mathrm{O}_{5}$, bridged by two carbonato ligands. Four bridging methoxy groups are located at each corners of the framework and the alkyl chains are located on either side of the inorganic plane. Tin residues collected in run 5 and 6 contain both species, 1 and $\left(n-\mathrm{Bu}_{2} \mathrm{SnO}\right)_{6}[(n-$ $\left.\left.\mathrm{Bu}_{2} \mathrm{SnOCH}_{3}\right)_{2}\left(\mathrm{CO}_{3}\right)\right]_{2}$. In terms of DMC produced, the mixture leads to a concomitant benefit. A better activity is observed (Fig. 2, run 5 and 6). In addition to the dehydration action of DMP, this can be explained by the in situ formation of $\mathrm{Sn}-\mathrm{OCH}_{3}$ bonds which are known to exhibit a great reactivity towards $\mathrm{CO}_{2}$ and leading to hemicarbonate moieties $\left(\mathrm{Sn}-\mathrm{OC}(\mathrm{O}) \mathrm{OCH}_{3}\right)$ [10]. Such reminiscent methoxy groups are observable in bridging positions in the structure of ( $n$ $\left.\mathrm{Bu}_{2} \mathrm{SnO}\right)_{6}\left[\left(n-\mathrm{Bu}_{2} \mathrm{SnOCH}_{3}\right)_{2}\left(\mathrm{CO}_{3}\right)\right]_{2}$. Moreover, in absence of dehydrating agent, the initial spectrum of $\mathbf{1}$ is fully recovered (Figure S7c). The characteristic infrared bands of the decanuclear tin species disappear. Thus, these observations point a direct link existing between $\left(n-\mathrm{Bu}_{2} \mathrm{Sn}\right)_{2} \mathrm{O}\left(\mathrm{CO}_{3}\right)$ and $\left(n-\mathrm{Bu}_{2} \mathrm{SnO}\right)_{6}\left[\left(n-\mathrm{Bu}_{2} \mathrm{SnOCH}_{3}\right)_{2}\left(\mathrm{CO}_{3}\right)\right]_{2}$, which implies a reversible process.

The stannane complex $n-\mathrm{Bu}_{2} \mathrm{Sn}\left(\mathrm{OCH}_{3}\right)_{2}$ is recognized as one of the most active and selective molecular organometallic species for DMC synthesis [19]. Often considered as a reference, its reactivity towards $\mathrm{CO}_{2}$ was widely studied, experimentally and by modelling [20]. To assess the activity of $\mathbf{1}, n-\mathrm{Bu}_{2} \mathrm{Sn}\left(\mathrm{OCH}_{3}\right)_{2}$ was used as precursor under the same reaction conditions $\left(150{ }^{\circ} \mathrm{C}, 200 \mathrm{bar}\right)$. Using four mmoles of $n$ - $\mathrm{Bu}_{2} \mathrm{Sn}\left(\mathrm{OCH}_{3}\right)_{2}$, a DMC/Sn ratio of 0.85 
was found after a reaction time of $24 \mathrm{~h}$. The activity of $\mathbf{1}$ is thus lower (almost divided by two) but $\left(n-\mathrm{Bu}_{2} \mathrm{Sn}\right)_{2} \mathrm{O}\left(\mathrm{CO}_{3}\right)$ has the advantage to be easily manipulated in ambient air, which is not the case with $n-\mathrm{Bu}_{2} \mathrm{Sn}\left(\mathrm{OCH}_{3}\right)_{2}$, easily hydrolyzable. Moreover, the examination by FT-IR of the collected residual material (white powder) at the end of the experiment conducted with $n$ $\mathrm{Bu}_{2} \mathrm{Sn}\left(\mathrm{OCH}_{3}\right)_{2}$, exhibits very strong similarities with the fingerprint of 1 (Figure S8). The two spectra are very close demonstrating a strong relationship between the two compounds. A possible pathway of transformation of $n-\mathrm{Bu}_{2} \mathrm{Sn}\left(\mathrm{OCH}_{3}\right)_{2}$ into $\mathbf{1}$ is reported in equation 3, involving the in situ formation of $n-\mathrm{Bu}_{2} \mathrm{SnO}$.

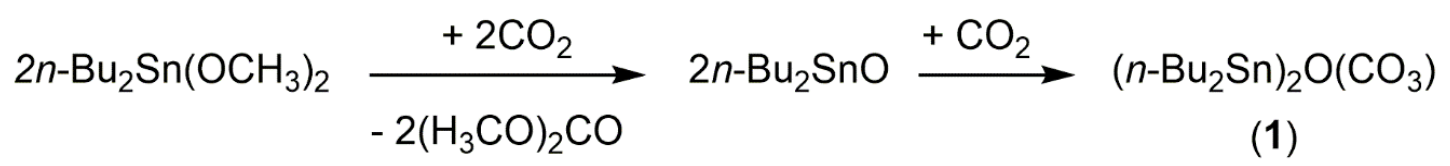

In parallel of these experiments, the optimization of reaction conditions was conducted. The influence of pressure and reaction time on DMC formation were successively investigated. As shown in Figure 3, the DMC yield was found to increase linearly with the pressure. Previously, this strong effect of the pressure on the reaction was also observed by Sakakura and co-workers when using $\mathrm{Bu}_{2} \mathrm{Sn}\left(\mathrm{OCH}_{3}\right)_{2}$ as tin precursor. Pressures above 1000 bar were then tested [19]. In our case and because of the limitations of our equipment it was not possible to continue beyond 200 bars. However the impact is already significant. The influence of reaction time on the amount of DMC was also studied (Figure 4). From $15 \mathrm{~h}$, the activity slows and reaches a plateau beyond $20 \mathrm{~h}$ of reaction. Thus, a duration of $24 \mathrm{~h}$ has been selected as the optimized reaction time. 


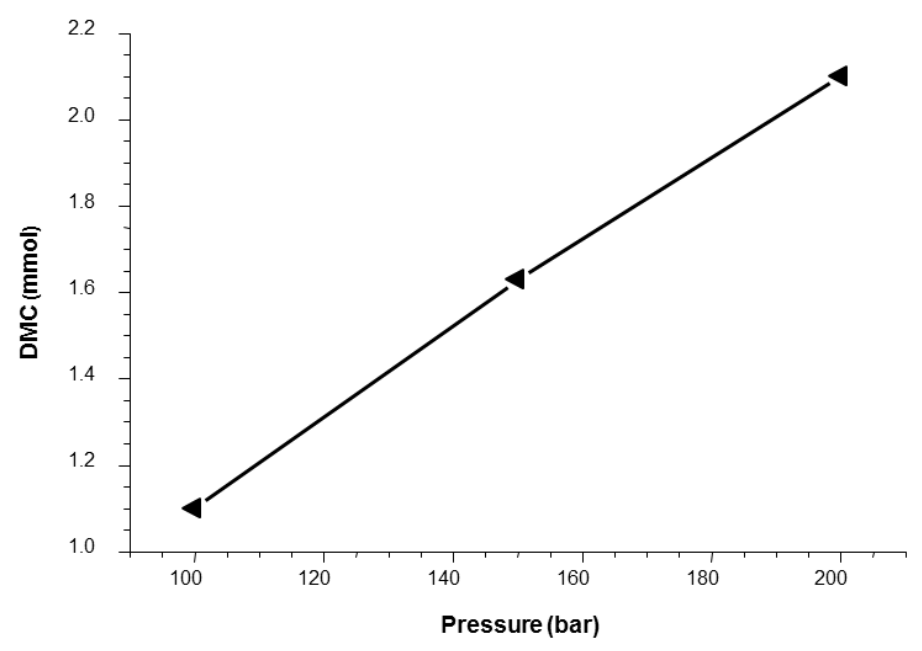

Figure 3. Effect of pressure on the amount of DMC. Reaction conditions: $20 \mathrm{~mL}$ of $\mathrm{MeOH}, 4$ mmol of $\mathbf{1}$, reaction temperature $150^{\circ} \mathrm{C}$, reaction time $24 \mathrm{~h}$.

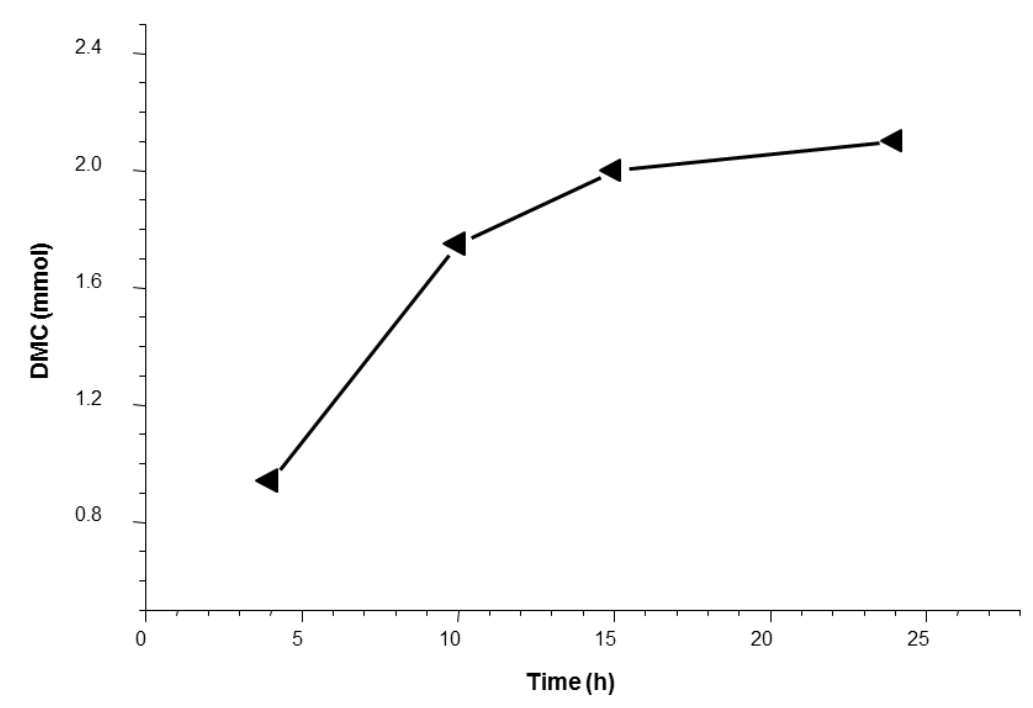

Figure 4. Effect of reaction time on the amount of DMC. Reaction conditions: $20 \mathrm{~mL}$ of $\mathrm{MeOH}$, $4 \mathrm{mmol}$ of $\mathbf{1}$, reaction temperature $150{ }^{\circ} \mathrm{C}$, pressure 200 bar.

The initial aim of this work was also to design a versatile tin precursor for the synthesis of linear dialkyl organic carbonates. Therefore the activity of $\mathbf{1}$ was extended to the direct carbonation of higher alcohols: (i) ethanol, (ii) n-butanol and (iii) isopropanol. The corresponding amounts of diethyl carbonate (DEC), di- $n$-butyl carbonate (DBC) and di- 
isopropyl carbonate (DIPC) are reported in Figure 5 and compared to that obtained for the DMC. 1 is active for the conversion of ethanol into DEC but it is less effective than for the synthesis of DMC. Similarly, 1 can be efficiently recycled several times for the synthesis of DEC (Figure 6). However the activity decreases drastically for the synthesis of DBC and is almost nil for the DIPC. In previous studies on the synthesis of DMC [12b] we showed that the yield of carbonates was closely related to the phase diagram of the $\mathrm{CO}_{2}$ /methanol binary mixture and was closely linked to the supercritical properties of the reaction medium. Indeed, we determined experimentally and by simulation that the optimal conditions were obtained when the pressure-temperature parameters are above the critical point of the mixture (monophasic medium). One hypothesis to explain the fall in activity of $\mathbf{1}$ could be that the $P-T$ conditions are not sufficient in cases of $n$-butanol and isopropanol. These parameters should be optimized to approach the expected supercritical conditions of the mixtures. Work in this direction are currently in progress.

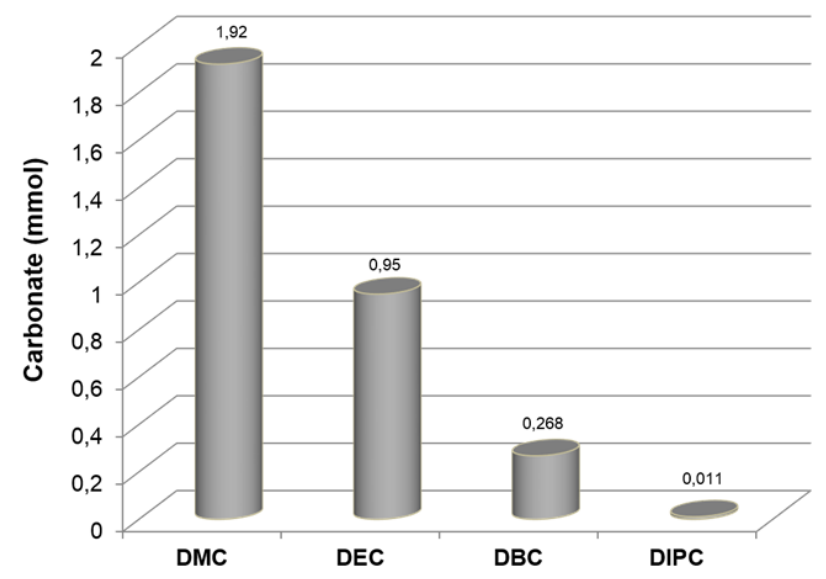

Figure 5. Comparison of activity of $\mathbf{1}$ for the synthesis of higher dialkyl carbonates. 


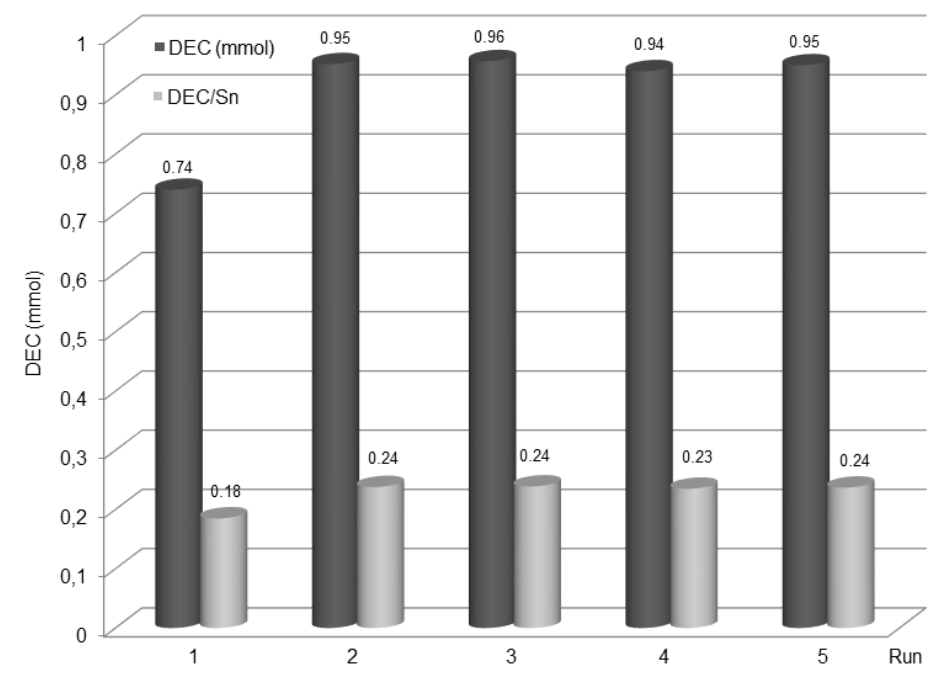

Figure 6. Recycling experiments. Reaction conditions: EtOH (20 mL), 4 mmol of 1 (run 1), reaction temperature $150^{\circ} \mathrm{C}$, pressure 200 bar, reaction time $24 \mathrm{~h}$.

\section{Conclusion}

We have shown that complex $\mathbf{1},\left(n-\mathrm{Bu}_{2} \mathrm{Sn}\right)_{2} \mathrm{O}\left(\mathrm{CO}_{3}\right)$, prepared in one step from a commercial precursor, is active under carbon dioxide pressure for the conversion of methanol into dimethyl carbonate. Recyclable several times without loss of activity, $\mathbf{1}$ has the advantage to be robust, undergoing few deterioration even after high pressure runs. Compared to the diorganotin dialkoxide complexes, which are recognized as being the most effective promoters for the direct carbonation of alcohols, $\mathbf{1}$ is air-stable and can be stored for several months without notable modifications. Moreover, $\mathbf{1}$ is a versatile precursor and can also be used in the presence of ethanol and $n$-butanol leading to the synthesis of diethyl carbonate and di- $n$-butyl carbonate, respectively. However, $\mathbf{1}$ is not active in the presence of isopropanol. From a mechanistic point of view, the use of 2,2-dimethoxypropane have highlighted an interconnection between $\mathbf{1}$ and the decameric oxocluster $\left(n-\mathrm{Bu}_{2} \mathrm{SnO}\right)_{6}\left[\left(n-\mathrm{Bu}_{2} \mathrm{SnOCH}_{3}\right)_{2}\left(\mathrm{CO}_{3}\right)\right]_{2}$. The formation of $\mathbf{1}$ was also clearly observed when $n-\mathrm{Bu}_{2} \mathrm{Sn}\left(\mathrm{OCH}_{3}\right)_{2}$ is used as precursor. Thus, $(n-\mathrm{Bu} 2 \mathrm{Sn})_{2} \mathrm{O}\left(\mathrm{CO}_{3}\right)(\mathbf{1})$ can 
be viewed as a key-intermediate. Further work is currently underway to deepen the links existing between these species.

\section{Experimental Section}

\section{General Aspects}

All manipulations were carried out by using standard Schlenk techniques or a stainless steel reactor. Methanol, ethanol, $n$-butanol and isopropanol (Carlo Erba, RPE grade) were dried with suitable drying agents and distilled under argon. Carbon dioxide N45 TP purchased from Air Liquide was used without further purification. $n-\mathrm{Bu}_{2} \mathrm{SnCl}_{2}$ (purity $\geq 98 \%$ ), dimethyl carbonate (purity $\geq 99 \%$ ), diethyl carbonate (purity $\geq 99 \%$ ), and 2,2-dimethoxypropane (purity $\geq 98 \%$ ) were purchased from Sigma-Aldrich, and were used without further purification. IR spectra were recorded on a Bruker Vector 22 equipped with a Specac Golden Gate ${ }^{\mathrm{TM}}$ ATR device. ${ }^{1} \mathrm{H}$, ${ }^{13} \mathrm{C}\left\{{ }^{1} \mathrm{H}\right\}$, and ${ }^{119} \mathrm{Sn}\left\{{ }^{1} \mathrm{H}\right\}$ NMR spectra were recorded at $300 \mathrm{~K}$ in $\mathrm{CH}_{3} \mathrm{OD}$ on Bruker Avance $300 \mathrm{MHz}$ and $500 \mathrm{MHz}$ spectrometers. ${ }^{119} \mathrm{Sn}\left\{{ }^{1} \mathrm{H}\right\}$ chemical shifts were reported downfield from $\left(\mathrm{CH}_{3}\right)_{4} \mathrm{Sn}$ used as external standard. Thermogravimetric analyses (TGA) were performed on a TA Instruments TGA Q500 thermoanalyzer using aluminum pans. Samples were heated at a rate of $5{ }^{\circ} \mathrm{C} \mathrm{min}^{-1}$ under flowing nitrogen gas. The gas flow rate at the sample was $60 \mathrm{~mL} \mathrm{~min}{ }^{-1}$, while the balance flow rate was $40 \mathrm{~mL} \mathrm{~min}^{-1}$. Weight loss percentages and onset temperatures were determined using the TA Universal Analysis 2000 software dedicated to the instrument. Elemental analyses and ICP-AES measurements were performed at the "Plateforme d'Analyse Chimique et de Synthèse Moléculaire de l'Université de Bourgogne (PACSMUB)', on a Fisons EA 1108 CHNS-O apparatus and a Thermo Scientific iCAP 7400 Series analyser, respectively.

\section{Preparation of $\left(n-\mathrm{Bu}_{2} \mathrm{Sn}\right)_{2} \mathrm{O}(\mathrm{CO})_{3}(1)$}


A methanolic solution of di- $n$-butyltin dichloride $\left(3.09 \mathrm{~g}, 0.01 \mathrm{~mol}, 15 \mathrm{~mL} \mathrm{CH}_{3} \mathrm{OH}\right)$ was mixed slowly with $15 \mathrm{~mL}$ of an aqueous solution of sodium carbonate $(1,06 \mathrm{~g}, 0.01 \mathrm{~mol})$. The white solid, which precipitated immediately, was then transferred to a $125 \mathrm{~mL}$ stainless steel reactor and the mixture was heated under $\mathrm{CO}_{2}$ atmosphere at $150{ }^{\circ} \mathrm{C}$ for $24 \mathrm{~h}\left(P_{\text {total }}=60\right.$ bar $)$. After the reaction, the excess of $\mathrm{CO}_{2}$ was removed slowly and the resultant solid was filtered and washed several times with de-ionized water, then dried under vacuum at $100{ }^{\circ} \mathrm{C}$ for $3 \mathrm{~h}$. The dry material was finally stored under argon atmosphere for future use.

${ }^{1} \mathrm{H}$ NMR $\left(\mathrm{CD}_{3} \mathrm{OD}, 300 \mathrm{~K}, \mathrm{ppm}\right): \delta 0.96\left(\mathrm{t},{ }^{3} J_{\mathrm{H}-\mathrm{H}}=6.7 \mathrm{~Hz}, 12 \mathrm{H}\right), \delta 1.49(\mathrm{~m}, 16 \mathrm{H}), \delta 1.71(\mathrm{~m}$, $8 \mathrm{H}) ;{ }^{13} \mathrm{C}\left\{{ }^{1} \mathrm{H}\right\} \mathrm{NMR}\left(\mathrm{CD}_{3} \mathrm{OD}, 300 \mathrm{~K}, \mathrm{ppm}\right): \delta 14.02,14.07,24.03\left({ }^{1} J_{\mathrm{CSn}}=600 \mathrm{~Hz}\right), 28.09$, 28.29, 28.49, 28.58, 28.72, 160.12; ${ }^{119} \mathrm{Sn}\left\{{ }^{1} \mathrm{H}\right\}$ NMR (CD $\left.3 \mathrm{OD}, 300 \mathrm{~K}, \mathrm{ppm}\right): \delta-173.5,-205.8$. IR $\left(\mathrm{cm}^{-1}\right):$ 2956, 2924, 2871, 2857, 1507, 1464, 1371, 1287, 1156, 1078, 869, 826, 675, 617. Anal. Calc. For $\mathrm{C}_{17} \mathrm{H}_{36} \mathrm{O}_{4} \mathrm{Sn}_{2}$ (541.88): C, 37.68; H, 6.70. Found: C, 37.69.; H, 7.02\%.

\section{High Pressure organic carbonates synthesis}

Safety Warning: Experiments involving pressurized gases can be hazardous and must only be conducted with suitable equipment and following appropriate safety considerations [20].

The reaction was carried out in a $125 \mathrm{~mL}$ stainless steel reactor equipped with a magnetic stirrer. The reactor was purged with argon and a $20 \mathrm{~mL}$ suspension of $\mathbf{1}$ in the required alcohols (methanol, ethanol, $n$-butanol or isopropanol) was introduced by syringe. Then, $\mathrm{CO}_{2}$ was admitted to the desired amount (32 g). The reaction temperature was controlled by an internal thermocouple. After a reaction time of $24 \mathrm{~h}$ the reactor was cooled down to $0{ }^{\circ} \mathrm{C}$, the pressure was gently released and the liquid phase was transferred to a Schlenk tube. Trap-totrap distillation under vacuum at ambient temperature allowed separation of volatile compounds that were quantitatively analyzed by GC (DEC external standard, Thermo Scientific FOCUS 
GC, TR-Wax $30 \mathrm{~m}$ capillary column, FID detector). The tin-based residue was characterized by IR spectroscopy and elemental analyses.

\section{Acknowledgments}

We gratefully acknowledge the Institut de Chimie of the Centre National de la Recherche Scientifique (CNRS-INC, France) and the Agence Nationale de la Recherche (ANR, France, Grant ANR-08-CP2D-18) for support of this work and a postdoctoral grant to S.R.S. We thank also Mr. Marcel Soustelle, the Dr. Myriam Heydel, and the Dr Lucie Chupin for elemental analyses, ICP-AES measurements and improvement of the manuscript, respectively. We are also grateful to the anonymous reviewers for their helpful and relevant comments which have significantly contributed to enhance the content of this manuscript.

\section{References}

[1] Non-exhaustive list of review articles published since 2012: a) I. Omae, Coord. Chem. Rev. 2012, 256, 1384; b) M. Holscher, C. Gurtler, W. Keim, T.E. Muller, M. Peters , W. Leitner, Z. Naturforsch. 2012, 67b, 961; c) M. Aresta, A. Dibenedetto, A. Angelini, Antonella, J. CO2 Util. 2013, 3-4, 65; d) M. Aresta, A. Dibenedetto, A. Angelini, Chem. Rev. 2014, 114, 1709; e) A. Dibenedetto, A. Angelini, P. Stufano, J. Chem. Technol. Biotechnol. 2014, 89, 334; f) G. Fiorani, W. Guo, A.W. Kleij, Green Chem., 2015, 17, 1375; g) A. Otto, T. Grube, S. Schiebahn, D. Stolten, Energy Environ. Sci., 2015, 8, 3283; h) S. Das, F.D. Felix, A. Gopakumar, P.J. Dyson, Chimia 2015, 69, 765; i) Q. Liu, L. Wu, R. Jackstell, M. Beller, Nature Comm. 2015, 6, 5933; j) H. Wang, P. Gao, T. Zhao, W. Wei, Y. Sun, Sci. China Chem. 2015, 58, 79.

[2] Examples of events planned in 2016: ICCDU XIV - International Conference on Carbon Dioxide Utilisation / Sheffield, $7^{\text {th }}$ Carbon Dioxide Utilisation Summit / Lyon; $5^{\text {th }}$ Conference 
on Carbon Dioxide as Feedstock for Fuels, Chemistry and Polymers / Cologne; Closing the Carbon Cycle: Fuels from Air / Phoenix.

[3] a) B. Schaffner, F. Schaffner, S.P. Verevkin, A. Borner, Chem. Rev. 2010, 110, 4554; b) S. Huang, B. Yan, S. Wang, X. Ma, Chem. Soc. Rev. 2015, 44, 3079.

[4] C. Martín, G. Fiorani, A.W. Kleij, ACS Catal. 2015, 5, 1353.

[5] a) J. Kizlink, Collect. Czech. Chem. Commun. 1993, 58, 1399; b) J. Kizlink, I. Pastucha, Collect. Czech. Chem. Commun. 1995, 60, 687.

[6] a) D. Ballivet-Tkatchenko, O. Douteau, S. Stutzmann, Organometallics 2000, 19, 4563; b) M. Aresta, A. Dibenedetto, C. Pastore, Inorg. Chem. 2003, 42, 3256; c) K. Kohno, J.-C. Choi, Y. Ohshima, A. Yili, H. Yasuda, T. Sakakura, J. Organomet. Chem. 2008, 693, 1389; d) Y. Masui, S. Haga, M. Onaka, Chem. Lett. 2011, 40, 1408; e) S. Petr, R. Olejník, Z. Padelkova, A. Ruzicka, L. Plasseraud, J. Organomet. Chem. 2012, 708-707, 82.

[7] a) B. Fan, H. Li, W. Fan, Z. Qin, R. Li, Pure Appl. Chem. 2011, 84, 663; b) D. BallivetTkatchenko, F. Bernard, F. Demoisson, L. Plasseraud, S. Reddy Sanapureddy, ChemSusChem 2011, 4, 1316; c) B. Fan, H. Li, W. Fan, J. Zhang, R. Li, Appl. Catal. A 2010, 372, 94; d) M. Aresta, A. Dibenedetto, F. Nocito, A. Angelini, G. Bartolo, S. De Negri, Appl. Catal. A 387 2010 113; e) B. Fan, J. Zhang, R. Li, W. Fan, Catal. Lett. 2008, 121, 297.

[8] a) K.-I. Tominaga, Y. Sasaki, Synlett 2002, 307; b) S. Pulla, C.M. Felton, Y. Gartia, P. Ramidi, A. Ghosh, ACS Sustainable Chem. Eng. 2013, 1, 309.

[9] N. Germain, I. Müller, M. Hanauer, R.A. Paciello, R. Baumann, O. Trapp, T. Schaub, ChemSusChem 2016, 9, 1.

[10] a) D. Ballivet-Tkatchenko, T. Jerphagnon, R. Ligabue, L. Plasseraud, D. Poinsot, Appl. Catal. A 2003, 255, 93. b) D. Ballivet-Tkatchenko, H. Chermette, L. Plasseraud, O. Walter, Dalton Trans. 2006, 5167. 
[11] a) G. Laurenczy, M. Picquet, L. Plasseraud, J. Organomet. Chem. 2011, 696, 1904; b) G. Laurenczy, A. F. Dalebrook, M. Picquet, L. Plasseraud, J. Organomet. Chem. 2015, 796, 53.

[12] a) D. Ballivet-Tkatchenko, R. Burgat, S. Chambrey, L. Plasseraud, P. Richard, J. Organomet. Chem. 2006, 691, 5167; b) D. Ballivet-Tkatchenko, S. Chambrey, R. Keiski, R. Ligabue, L. Plasseraud, P. Richard, H. Turunen, Catal. Today 2006, 115, 80.

[13] L. Plasseraud, D. Ballivet-Tkatchenko, H. Cattey, S. Chambrey, R. Ligabue, P. Richard, R. Willem, M. Biesemans, J. Organomet. Chem. 2010, 695, 1618.

[14] a) A.J. Bloodworth, A.G. Davies, S.C. Vasishtha, J. Chem. Soc. C 1967, 1309; b) R.G. Goel, H.S. Prasad, G.M. Bancroft, T.K. Sham, Can J. Chem. 1976, 54, 711; c) P.J. Smith, R. Hill, A. Nicolaides, J.D. Donaldson, J. Organomet. Chem. 1983, 252, 149; d) S.J. Blunden, R. Hill, J.N.R. Ruddick, J. Organomet. Chem. 1984, 267, C5.

[15] a) S. Knoll, F. Tschwastschal, T. Ristau, T. Gelbrich, R. Borsdorf, G. Zahn, Z. Anorg. All. Chem. 1997, 623, 141; b) G.-L. Zheng, J.-F. Ma, J. Yang, Y.-Y. Li, X.-R. Hao, Chem. Eur. J. 2004, 10, 3761; c) Z. Padelkova, H. Vankatova, I. Cisarova, M.S. Nechaev, T.A. Zevaco, O. Walter, A. Růžička, Organometallics 2009, 28, 2629; d) L. Plasseraud, H. Cattey, P. Richard; Z. Naturforsch. 2010, 65b, 1293; e) H. Reuter, H. Wilberts, Can. J. Chem. 2014, 92, 496.

[16] a) E.R.T Tiekink, J. Organomet. Chem. 1986, 302, C1; b) J. Kummerlen, A. Sebald, H. Reuter, J. Organomet. Chem. 1992, 427, 309; c) S.-L. Li, G.-J. Ping, J. Liu, J.-F. Ma, Z.-M. Su, Inorg. Chem. Commun, 2008, 11, 220; d) S.U. Ahmad, J. Beckmann, A. Duthie, Chem. Asian. J. 2010, 5, 160; e) A.-E. Ghionoiu, D.-L. Popescu, C. Maxim, A.M. Madalan, I. Haiduc, M. Andruh, Inorg. Chem. Commun, 2015, 58, 71.

[17] B. Mairychová, L. Dostál, A. Růžička, L. Beneš, R. Jambor, J. Organomet. Chem. 2012, $699,1$.

[18] S. Wang, J. Zhou, S. Zhao, Y. Zhao, X. Ma, Chem. Eng. Technol. 2016, 39, 723. 
[19] a) T. Sakakura, J.-C. Choi, Y. Saito, T. Masuda, T. Sako, T. Oriyama, J. Org. Chem. 1999, 65, 4506; b) T. Sakakura, J.-C. Choi, Y. Saito, T. Sako, Polyhedron 2000, 573.

[20] a) M. Poor Kalhor, H. Chermette, S. Chambrey, D. Ballivet-Tkatchenko, Phys. Chem. Chem. Phys., 2011, 13, 2401. B) S. Chambrey, M. Poor Kalhor, H. Chermette, D. BallivetTkatchenko, J. Braz. Chem. 2014, 25, 2350.

[21] N.S. Isaacs, A. Sharp, Safety Procedures for High-Pressure Systems, in: W.B. Holzapfel, N.S. Isaacs (Eds), High-Pressure Techniques in Chemistry and Physics, Oxford University Press, 1997, pp. 381-384. 